\title{
Gut regulatory peptides as mediators of gastrointestinal tract growth, motility and development of secretion in young ruminants
}

\author{
P. Guilloteau ${ }^{1}$ and R. Zabielski ${ }^{2,3}$ \\ ${ }^{1} U M R-S E N A H$, Institut National de la Recherche Agronomique \\ 35-590 Saint-Gilles, France \\ ${ }^{2}$ Warsaw Agricultural University, \\ Department of Physiological Sciences, Faculty of Veterinary Medicine \\ Nowoursynowska 159, 02-776 Warsaw, Poland \\ ${ }^{3}$ The Kielanowski Institute of Animal Physiology and Nutrition, Polish Academy of Sciences \\ 05-110 Jablonna, Poland
}

\begin{abstract}
In mammalian species, the prenatal development of foetal tissues is programmed to result in the organization of different functions of the organism. During development, non-genetic factors are involved and act through regulatory substances. It is frequently said that the GIT represents "the largest endocrine organ in the body". Most of these substances depend on an intricate regulatory complex increasingly recognized as a unique system having multiple aspects, including hormonal, nervous and immune ones. The link in this unique system comprises a number of substances whose task is to translate the signals. Among them, the gut regulatory peptides are considered to be substances that play a pivotal role in digestive functions. This review will deal with recent advances in the regulation of digestive functions in which the gut regulatory peptides are involved during development in calf i.e., during foetal life, after birth, during maintenance at the preruminant stage, and at weaning. This report will be devoted in particular to gut regulatory peptides as mediators of gastrointestinal (GI) growth, motility and development of secretion and adaptations. Increasing knowledge about the biological functions and mechanisms of gut regulatory peptide actions could help in managing the growth and maturation of the gastrointestinal tract (GTI), to better optimize digestive motility and productions. It is particularly important in the young to help them to better pass through such critical stages as the neonatal and weaning periods.
\end{abstract}

KEY WORDS: ruminant, calf, gut regulatory peptides, digestive tract, motility, digestive secretions

Corresponding author: e-mail: Paul.Guilloteau@rennes.inra.fr 


\section{INTRODUCTION}

In mammalian species, the prenatal development of foetal tissues is programmed to result in the organization of different functions of the organism. The digestive system is formed mainly during the first trimester of gestation. During the last trimester, the development of the gastrointestinal tract (GI tract or GIT) is completed and is ready to begin enteral feeding. During the first month after birth, the calf may have to deal with different situations that require severe adaptation of digestive functions. First, it has to adapt to extra-uterine life and digestion of colostrum and milk. Second, it can be maintained at a preruminant stage and finally weaned to solid food (Guilloteau et al., 2005). In the first and second stages, the calf is given milk and/or milk substitutes of varying composition, in the last stage, it is offered solid feeds and decreasing amounts of milk until weaning is completed.

Many studies have been reported on the anatomical, biochemical and physiological changes that occur during postnatal as well as prenatal development (Pavaux, 1977; Ruckebush, 1977; Roy, 1980; Kazari, 1994; Bloom, 2005a; Brameld, 2005). During the foetal period, it was shown that the foetus swallows amniotic fluid, which is rich in bioactive substances but of less relevance in regard to nutritive components. These are brought by the maternal blood circulation that crosses the placental barrier. In a young calf, ingested colostrum and milk go directly to the abomasum and digestion is similar to that observed in simplestomached animals; the calf is then called a preruminant. Following the age of one month, solid feeds can be ingested progressively. In comparison with preruminant animals, meals are more numerous, solid feeds are ingested more slowly, fall into the rumen and induce the development of microbial digestion. However, 5-6 weeks are required after weaning before intake of concentrate-rich diets is no longer limited by the reticulo-rumen size. During the day, the content of the digestive tract change less in ruminants than in preruminants and the end-products of digestion differ [volatile fatty acids (VFA) instead of glucose and long-chain fatty acids] (Thivend et al., 1980).

All of the above mentioned phenomena are regulated by a wide number of factors which are closely related each other. Firstly the chemical and mechanical properties are responsible of the milk clotting and gastric emptying in the preruminant calves (Guilloteau et al., 2005; Guilloteau and Zabielski, 2005). But most of them depend on an intricate regulatory complex increasingly recognized as a unique system with multiple aspects, including hormonal, nervous and immune ones (Besedovsky and Rey, 1996; Guilloteau et al., 2002). The link in this unique system comprises a number of substances whose task is to translate the signals. Among them, the gut regulatory peptides are considered to be substances that play a pivotal role in digestive functions. 
This review will deal with recent advances in the regulation of the digestive functions in which the gut regulatory peptides are involved during development of the calf i.e. during foetal life, after birth, during maintenance at the preruminant stage, and at weaning. This report will be devoted in particular to gut regulatory peptides as mediators of GIT growth, motility and development of secretion as well as adaptations.

\section{GUT REGULATORY PEPTIDES: AN OVERVIEW}

It is frequently said that the GIT represents "the largest endocrine organ in the body" (Thompson et al., 1987). Indeed, more than 100 regulatory substances are released from the gastrointestinal mucosa under a variety of conditions and from a variety of cells. Besides histamine and serotonin (important examples of non-peptide regulators) most of the other regulatory substances (often referred to as hormones) released by the enteroendocrine cells are peptides, and are generally referred to as gut regulatory peptides, considering that many of them are also released by the enteric neurons, as well as the immune system. But the gut regulatory peptides are also produced by non-GIT cells like those found in the brain, lungs and several other tissues. Regardless from which cell type they are released, and whether or not they have local or more distant sites of action, the signal transduction induced by gut regulatory peptides is mediated by selective receptors on the target cell surface. Most of these receptors belong to a superfamily of receptors that are known as the G-protein coupled receptors because of their intimate association with GTP-binding-proteins, and whose structure is characterized by seven hydrophobic transmembrane domains. It is the specific combination of G-protein subunits to which a receptor is coupled that ultimately determines the transduction response induced by the bound ligand. Thanks to new laboratory techniques these aspects have become clearer. Thus the chemical, biological and physiological characteristics of the main gut regulatory peptides, their receptors and their transductional systems are well documented in several books (Glass, 1980; Bloom and Polak 1981; Thompson et al., 1987; Heinz-Erian et al., 1992; Walsh and Docray, 1994; Coon and Goodman, 1998; Greely, 1999) and synthetic reviews (Guilloteau et al., 2002; Schneider and Sayegh, 2002; Williams, 2002).

The enormity and complexity of this unique system (with endocrine, neural and immune aspects) no doubt reflect its essential role in the coordination and regulation of gut functions, including in particular growth, gut motility and digestive productions. Thus, studies of the mechanisms involved are complicated by several aspects related to the way used by the gut regulatory peptides to reach the target cells: autocrine, paracrine, endocrine and/or neurocrine ways via blood 
circulation, interstitial fluid and/or gut lumen. The majority of the data available in the literature is based on studies performed in rodent laboratory animals, with large farm species not being used often. Thus, from a practical point, most of the data reported here has been obtained in young ruminant species using mainly complementary strategies such as: 1 . comparison of the pattern of the gut regulatory peptide plasma concentrations and digestion parameters for given factors, 2. effect of blood or gut lumen perfusion with gut regulatory peptides and/or specific pharmacological receptor antagonists on gut motility and digestive secretions. The former give descriptive information about the gut regulatory peptides that could be good candidates to explain the measured phenomena, whereas the latter can result in explaining the mechanisms involved. Concerning blood perfusion, it is important to distinguish physiological from pharmacological doses. Finally, comparative digestive physiology can help us to better understand the interspecies differences.

\section{GUT REGULATORY PEPTIDES AND GIT GROWTH (DEVELOPMENT AND MATURATION)}

\section{Foetal period}

In the 1980s, many studies were carried out to measure the concentrations of gut regulatory peptides in the tissues of the GIT and showed that, during the foetal period, each regulatory peptide is detected at different gestational ages depending on the mammalian species and digestive tissues (Oldham and Thompson, 1987), but no data are available in ruminant species. To our knowledge, the gut regulatory peptide concentrations in amniotic fluid, digestive content, placental and/or maternal and foetal plasma were measured during the last third of gestation in ovine and bovine species and only one study concerning a long period (between 3 and 9 months) is available in bovine species (Guilloteau et al., 1998a). Taking together these works, it can be concluded that in the ruminant foetus: 1 . the concentrations of gut regulatory peptides in plasma are independent from those measured in their dams, suggesting that independent synthesis and secretion occur in the foetus, 2 . due to the chemical conditions in the gut lumen, the gut regulatory peptides are stable in this milieu and their major source in the amniotic fluid is the enteral circulation of the fluid swallowed by the foetus, thus draining the luminal peptide contents caudally, 3 . gastrointestinal endocrine cells appear to be regulated, as shown by the decrease of plasma gastrin and pancreatic polypeptide (PP) concentrations upon somatostatin infusion in sheep foetus (Shulkes and Hardy, 1982), 4. the endocrine system for some peptides is functional as early the $3^{\text {rd }}$ month of gestation, and finally, 5. these diverse observations suggest that foetal 
endocrine cells release their secretory granules in a regulated manner, and that the peptides are capable of interfering with functional targets. Caution is, however, required in interpreting the results, since immunoreactivity is not sufficient to establish structural identity. In particular, gastrin and cholecystokinin (CCK) can be secreted as incompletely processed compounds, e.g., biologically inactive glycine-extended forms.

The gut regulatory peptides can act in an endocrine way but also locally through the luminal way and they can be involved early in gestation (as soon as, and probably before, 3 months). Thus, foetal swallowing of amniotic fluid is considered to be required for adequate development of the GIT, possibly via luminal trophic action of the regulatory peptides (Mulvihill at al., 1986). This hypothesis is substantiated by the changes in the development of intestinal mucosa when circulating concentrations of gastrin are decreased by antrectomy in sheep (Avila et al., 1989). Finally, several experiments that we have done show that during the foetal period, increases in the concentrations of gastrin and PP parallel abomasal (and abomasal mucosa) development (relative to liveweight, LW) whereas that of somatostatin does not change. In the same way, increasing concentrations of gastric inhibitory peptide or glucose dependent insulinotropic peptide (GIP) and CCK levels accompany pancreas development (Figure 1). This could suggest that those peptides may be implicated in the stimulation (gastrin, CCK) and/or inhibition (somatostatin) of the growth of the corresponding organs during gestation, as well as during development of the preruminant animal from birth to several months of age (Figure 1). Finally, the functionality of peptidergic structures is also advantageous for the peptide responses to feeding immediately at birth.

\section{Neonatal period}

Just after birth, the gut regulatory peptides present in colostrum and milk (Koldovky, 1989; Campana and Braumrucker, 1995; Zabielski, 1998; Bloom, 2005b) induce the postnatal development of the endocrine gut in controlling digestive functions until the endogenous regulatory systems are adequately developed. Thus, active or passive immunization against somatostatin results in an increase of growth (involving GIT) in the calf and lamb (Van Kessel et al., 1993; Van Kessel and Laarveld, 1994). As a remark, milk replacers are generally deprived of the gut regulatory peptides due to their inactivation by technological processes, in particular by heating (Rudloff and Lönnerdal, 1992; Rudloff and Kunz, 1997; Guilloteau et al., 2002).

In the neonatal calf, ingestion of 4 colostrum meals during the first $22 \mathrm{~h}$ of life, causes a marked rise in plasma concentrations of most of the gut regulatory peptides, including gastrin, secretin, CCK, vaso-intestinal polypeptide (VIP) and PP, with a cumulative effect for several of them, and a decrease in somatostatin 

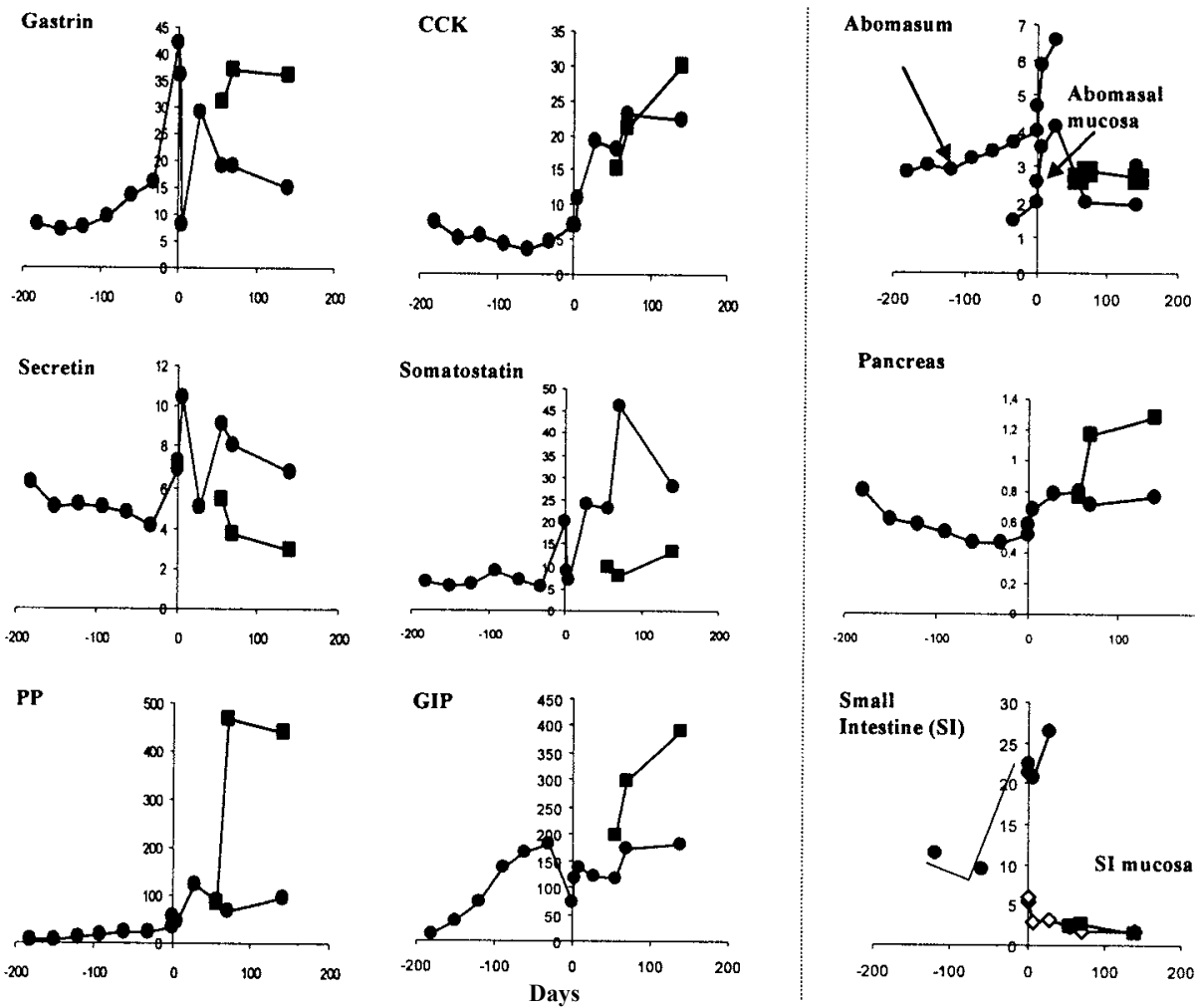

Pancreas
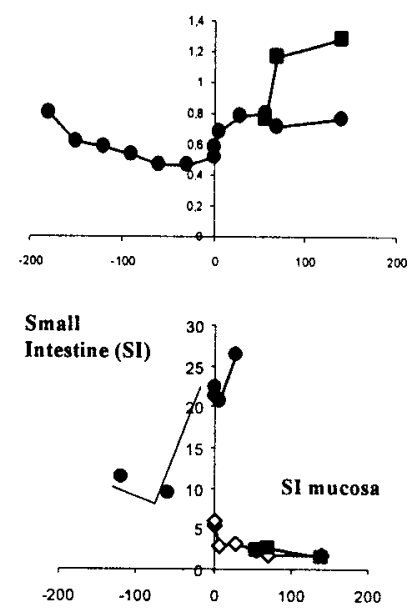

Figure 1. Evolution with age of plasma concentrations of six gut regulatory peptides (pmol/L) and abomasum, pancreatic and small intestinal weights relative to the body weight (\%) in bovine foetuses and preruminant $(\diamond)$ and ruminant $(\square)$ calves (adapted from Toofanian et al., 1974; Le Huërou-Luron et al., 1992; Toullec et al., 1992; Guilloteau et al., 1984a, 1992b, 1998a)

and motilin concentrations (Guilloteau et al., 1992a). Gastrin and CCK could have a favourable effect on GIT growth and digestive function since marked hyperplasia of the pancreas was observed in lambs (Guilloteau et al., 1983) as well as an increase in the protein content in small intestine mucosa (Le HuërouLuron et al., 1992) that was shown to be due to enhanced uptake of colostral proteins and increased protein synthesis. Indeed, duodenal morphology and stem cell proliferation are modified by feeding high amounts of first colostrum, which enhances the survival of mature mucosal epithelial cells (Blätter et al., 2001). CCK seems to be strongly involved in this control. On the one hand, receptor to gut peptide type 1 or $\mathrm{A}\left(\mathrm{CCK}_{1}\right)$ receptors have been demonstrated in the intestinal mucosa of calves and rats (Zabielski et al., 2002). On the other hand, blocking of the luminal $\mathrm{CCK}_{1}$ receptor by intraduodenal administration of a selective $\mathrm{CCK}_{1}$ receptor antagonist resulted in reduced size of crypts and villi width (but not villi length) in the small intestine, as well as reduced size of pancreatic acini. The mitotic 
index in the crypts was lower and the size of "lysosomal vacuoles" (a marker of gut mucosal maturity) as well as the percentage of vacuolated enterocytes in the jejunum and ileum were higher after treatment with a $\mathrm{CCK}_{1}$ receptor antagonist (Biernat et al., 1999). Interestingly, similar results were obtained in neonatal pigs suggesting that endogenous CCK may be an universal regulator of gut mucosa maturation (Biernat, 2002). Elimination from the diet of lactose, lipids, proteins and peptides other than immunoglobulins considerably changes the profile of plasma gut regulatory peptides (Guilloteau et al., 1997), including plasma leptin (Bloom et al., 2005), and may result in an unfavourable effect on gut motility, gastric and pancreatic secretion and absorptive function of the GIT.

During the first week of postnatal life, the relative weight of the abomasum and its mucosa, as well as that of the pancreas and small intestine, considerably increase. By contrast, that of small intestinal mucosa abruptly decreases (Guilloteau et al., 1998b; Figure 1). For this last observation, it has been noticed that the plasma gastrin concentration shows a similar trend, but it seems difficult to explain this phenomena only by comparing plasma levels of gut regulatory peptides. But for the other parts of the GIT, plasma levels of CCK and secretin are increased by 3.0 and 1.8 times, respectively. The leptin concentration increases from $\mathrm{d} 1$ to $\mathrm{d} 2$ and then remains elevated during the first week of age (Bloom et al., 2005). In contrast, the somatostatin concentration decreases or does not change. The evolution of these three gut regulatory peptides is in favour of the development of digestive organs, in particular, of the pancreas (Figure 1).

\section{Preruminant and ruminant periods}

In the calf, the basal plasma concentrations of gastrin, motilin and somatostatin decrease during the first 3 weeks of life (Guilloteau et al., 1992b; Toullec et al., 1992). The fall is particularly rapid for somastostatin, and it occurs between the first and second postnatal days. By contrast, the concentrations of secretin, CCK and PP increase, those of VIP and GIP do not change. Thereafter, no significant changes in relation to age are observed besides secretin, which tends to increase. In contrast, prandial concentrations after the morning meal significantly change with age. In the lamb, trends similar to those observed in calves were described by Shulkes and Hardy (1982) and Bell et al. (1984). Most of these changes are in agreement with the growth of organs (Figure 1) as well as the changes in the morphology of the small intestine (Figure 2). As an example, the increase of plasma CCK and the decrease of somatostatin favour increases in pancreas size. In the same way, the decrease of the relative weight of the abomasum, mainly its mucosa, could be explained, at least in part, by the lowered concentration of gastrin and enhanced concentration of somatostatin (Figure 1). This suggestion fully agrees with results obtained in another species, since circulating gastrin 

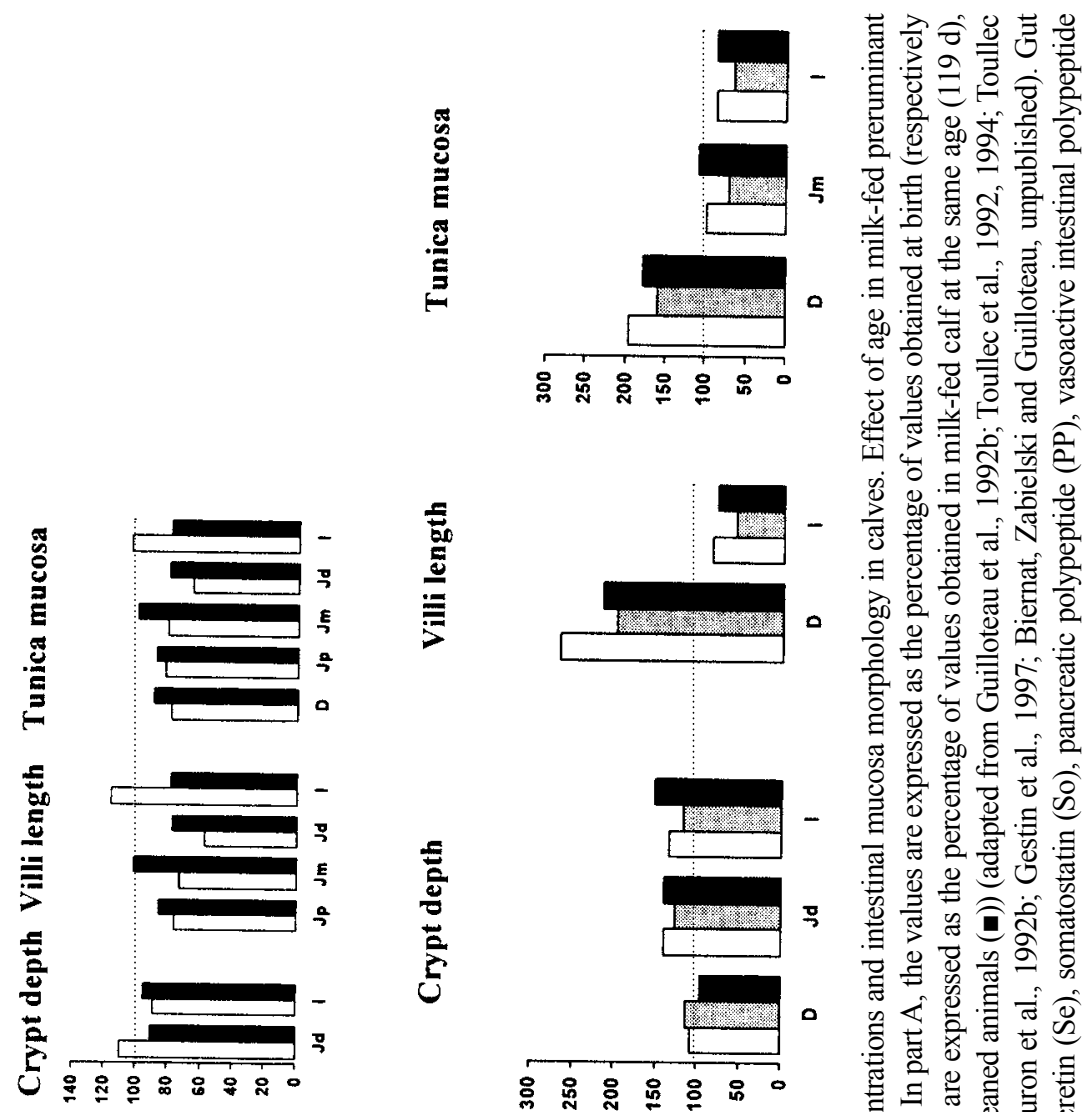

氙

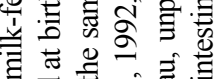

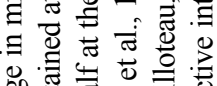
品考

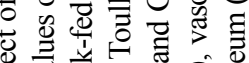

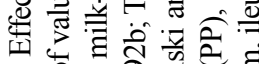
में

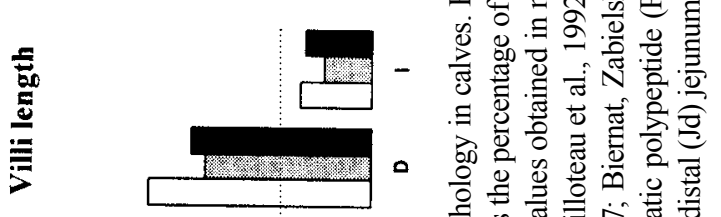

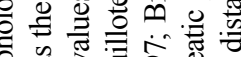
वे

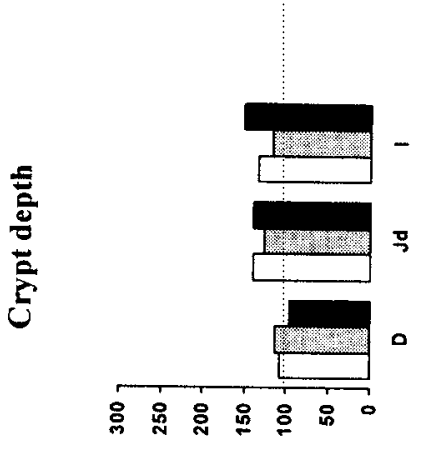

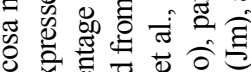

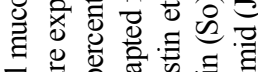

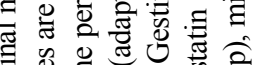

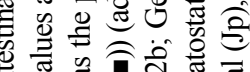

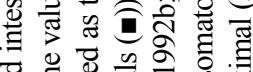

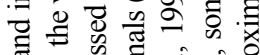

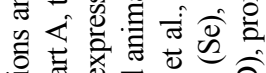

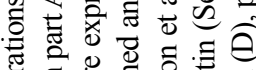

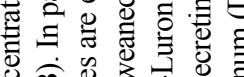

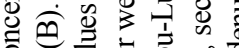

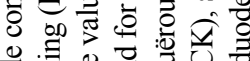

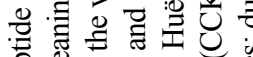

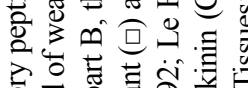

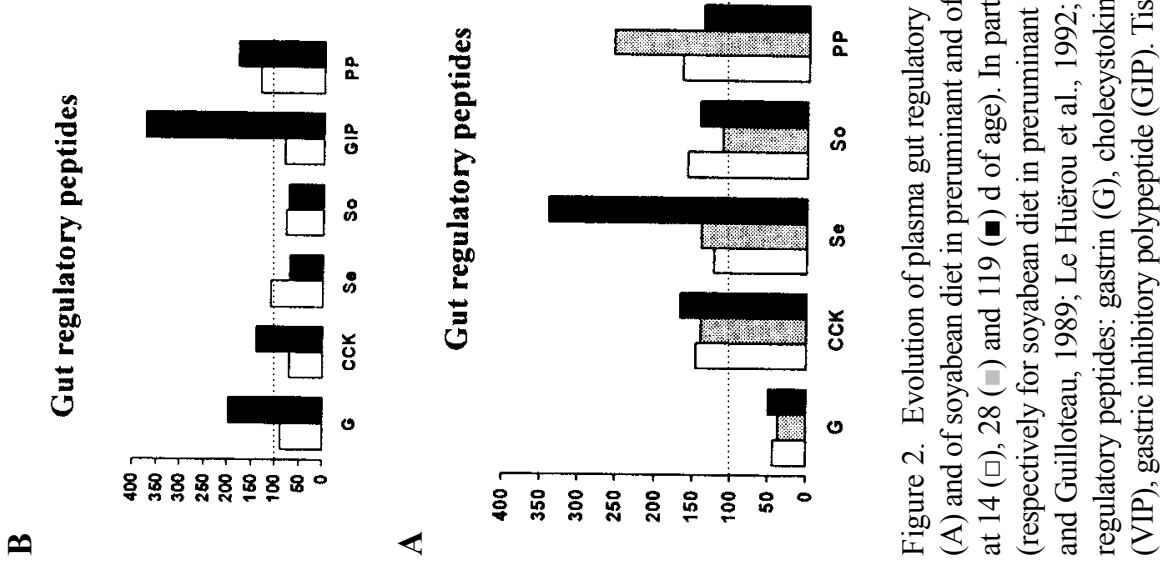


was shown to be a major regulator of oxyntic mucosa growth, and an important stimulator of gastric endocrine cell and intestinal mucosa growth (Walsh, 1994). In a similar way, in the small intestinal mucosa, the crypts and villi undergo intensive development in the early postnatal period, so 14 days after birth it does not change much, and the same holds for the plasma concentrations of the gut regulatory peptides (Figure 2). The replacement of milk protein by soyabean protein in the diet results in a reduction of intestinal crypt and villi size (mainly in the proximal small intestine), as well as a reduction in plasma concentrations of several gut regulatory peptides, suggesting that they may play a role in controlling stem cell proliferation and differentiation resulting in changes in mucosa morphometry (Figure 2).

In calves, progressive weaning between 28 and $56 \mathrm{~d}$ of age results in elevations in plasma gastrin, CCK, PP and GIP concentrations. In contrast, plasma secretin and somatostatin concentrations decrease in weaned calves in comparison with exclusively milk-fed animals. The changes in basal plasma gastrin, CCK and somatostatin concentrations induced by weaning should favour the development of the forestomachs, abomasal mucosa and the pancreas, as was observed by Le Huërou-Luron et al. (1992) in calves and by Guilloteau et al. (1998b) in lambs. Following the completion of weaning-related gastrointestinal modifications, i.e. in a 4-month-old calf, the plasma gut regulatory peptide concentrations stabilize their profile (Figure 2). Moreover, the increasing responses of plasma PP to feeding in ruminant calves reflects the development of parasympathetic control over forestomach function (Bloom et al., 1978). In rats PP was shown to inhibit the growth of gastric mucosa (Dembiński et al., 2004), but in lambs, it exerts a trophic action on the pancreas tissue (Shulkes and Hardy, 1982).

\section{GASTROINTESTINAL PEPTIDES AND DIGESTIVE PRODUCTIONS}

\section{Effect of age in preruminant fed milk replacer based on skim milk powder}

At birth, the enzyme contents of abomasal mucosa, pancreas (except for amylase) and intestinal mucosa (except maltase) are relatively high, confirming that considerable storage of most digestive enzymes takes place in the newborn (Guilloteau et al., 1983, 1984a, 1985; Le Huërou et al., 1992; Le Huërou-Luron et al., 1992; Gestin et al., 1997). The prenatal accumulation of enzymes may be related to enhanced synthesis that is stimulated by the prenatal peaks of several gut regulatory peptides (Guilloteau et al., 1998a) simultaneously with the relatively slow secretion in the foetal gut lumen. Thus in the neonate, the GIT is ready to start the digestive processes immediately after birth and to adapt itself to the meal content. 
During the 2-3 first days of life, the ingestion of colostrum meals results in modification of plasma gut regulatory peptides (see part - Neonatal period) including leptin and ghrelin (Bloom et al., 2005; Woliński et al., unpublished). At the same time, gastric enzyme contents increase, whereas those of the pancreas and small intestine, decrease (Guilloteau et al., 1983, 1984a, 1985; Le Huërou et al., 1992; Le Huërou-Luron et al., 1992; Gestin et al., 1997). One could say the changes in the pancreas and intestine may be related to the release of accumulated enzymes, but during this period at least the secretion of pancreatic juice is very low (Zabielski et al., 2002). The explanation is difficult since pancreatic secretion in the foetus is not known, but presumably there exists some secretion of pancreatic enzymes during the foetal period concurrently with low enzyme protein synthesis due to immature CCK-vagal-dependent regulatory mechanisms. In contrast, production of abomasal and intestinal enzymes is more dependent on the increasing plasma levels of the stimulatory gut regulatory peptides concomitantly with a reduction in the inhibitors. But lowering of the gastrin level during this time is in agreement with the decrease of chymosin content in the abomasal mucosa and with the lack of increase of pepsin and acid secretions (Guilloteau et al., 1980; Le Huërou-Luron et al., 1992). Caution is, however, required in speculating on the relationships between gastrin and chymosin, since, to our knowledge, until now, no data are available.

During the first $24 \mathrm{~h}$ of extra-uterine life, high plasma concentrations of CCK, secretin and VIP in concert with transiently increased vagal input during suckling may stimulate the secretion of pancreatic enzymes leading to a decrease in the enzyme content in the pancreas tissue (Guilloteau et al., 1984a; Le HuërouLuron et al., 1992; Zabielski et al., 2002). During this period, the distribution of a milk formula (with similar nutritive contents but not the composition of bioactive substances) or a saline solution containing purified immunoglobulins alone or supplemented with caseinomacropeptide, isobutyric acid or lyophylized colostrum extract (containing whey proteins except immunoglobulins), did not change the postprandial levels of the examined gut regulatory peptides (Guilloteau et al., 1997; Blatter et al., 2001). Thus, the biological substances such as hormones, growth factors, as well as gut regulatory peptides normally present in colostrum, are candidate substances that may push the stored digestive enzymes toward secretion.

After the colostral period during the first month of life, the quantities of all enzymes markedly increase in the abomasal and intestinal mucosa, and pancreas tissue in calves (Guilloteau et al., 1983, 1984a; Le Huërou et al., 1992; Le HuërouLuron et al., 1992; Gestin et al., 1997) as well as in the pancreatic juice (Zabielski et al., 2002) (Figure 3). This well explains the increase of faecal digestibility observed during this time by Grongnet et al. (1981) since nutrient absorption is related to the secretion of pancreatic enzymes (Guilloteau et al., 1999). Correlatively, in 
preruminant calves the concentrations of secretagogue gut regulatory peptides increase until the age of 3-4 weeks of life, and do not change thereafter as long as the calves are maintained preruminant (Toullec et al., 1992).

Plasma gut regulatory peptides

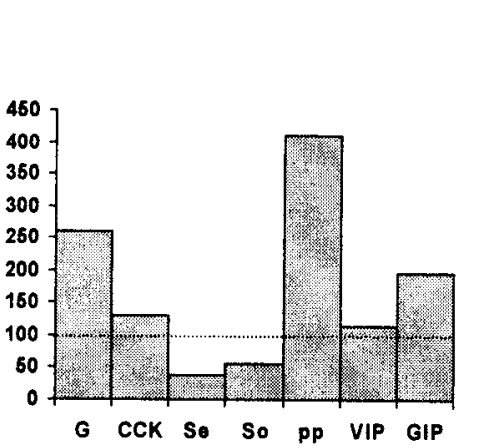

\section{Gastric productions}

Abomasal secretions

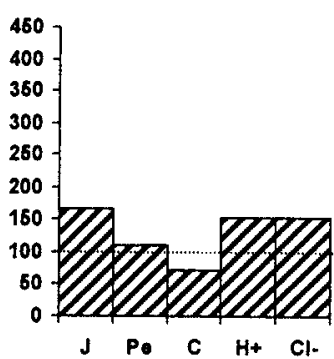

Abomasal mucosa content

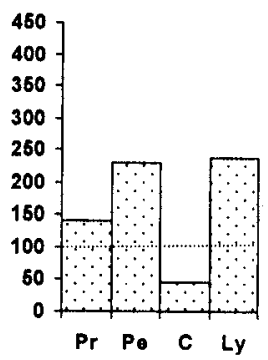

Pancreatic productions
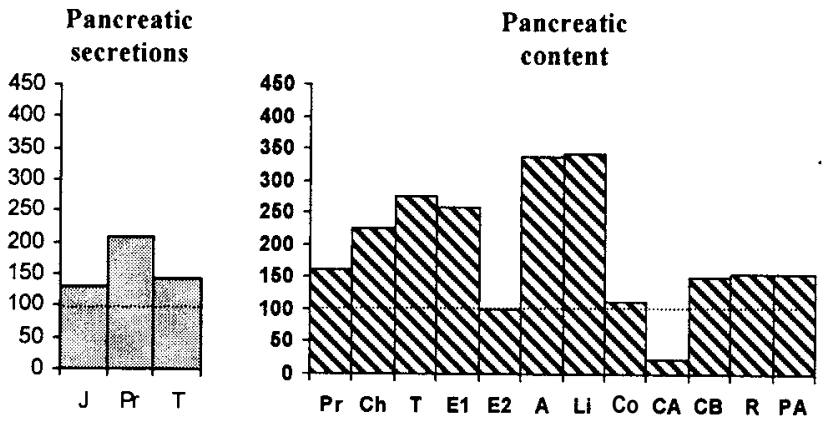

Intestinal productions

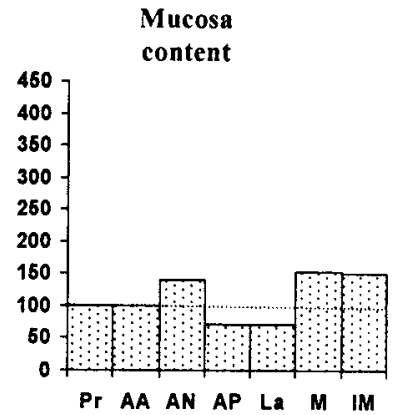

Figure 3. Effect of weaning on plasma gut regulatory peptide levels and on gastric, pancreatic and intestinal productions. The values measured in ruminant, are expressed as the percentage of that observed in preruminant of the same age. The original values used for calculation, are expressed as $\mathrm{nmol} / \mathrm{L}$ for gut regulatory peptides, quantitities and/or international units (IU) per $\mathrm{kg}$ of liveweight (LW) for juice and/or enzymes, $\mathrm{mEq} / \mathrm{kg}$ of LW for electrolytes (adapted from Guilloteau et al., 1992b; Le Huërou et al., 1992; Le Huërou-Luron et al., 1992; Toullec et al., 1992; Gestin et al., 1997; Guilloteau et al., unpublished)

Gut regulatory peptides: gastrin $(\mathrm{G})$, cholecystokinin (CCK), secretin (Se), somatostatin (So), pancreatic polypeptide (PP), vasoactive intestinal polypeptide (VIP), gastric inhibitory polypeptide (GIP)

Gastric productions: juice $(\mathrm{J})$, proteins $(\mathrm{Pr})$, pepsin $(\mathrm{Pe})$, chymosin $(\mathrm{C})$, lysosyme $(\mathrm{Ly})$, cation $\mathrm{H}^{+}$ $\left(\mathrm{H}^{+}\right)$, anion $\mathrm{Cl}^{-}\left(\mathrm{Cl}^{-}\right)$.

Pancreatic productions: juice $(\mathrm{J})$, proteins $(\mathrm{Pr})$, trypsin $(\mathrm{T})$, chymotrypsin $(\mathrm{Ch})$, elastases I (E1), and II (E2), amylase (A), lipase (Li), colipase (Co), carboxypeptidases A (CA) and B (CB), ribonuclease (R), phospholipase A2 (PA)

Intestinal productions: proteins (Pr), aminopeptidases $\mathrm{A}(\mathrm{AA})$ and $\mathrm{N}(\mathrm{AN})$, alcalin phosphatase (AP), lactase (La), maltase (M), isomaltase (IM) 


\section{Effect of meal and its composition}

In calves fed milk replacer based on skim milk proteins, feeding is followed by a long lasting increase of plasma gastrin and CCK, and a decline in secretin, motilin and somatostatin (Guilloteau et al., 1986b; Toullec et al., 1992; Le Dréan et al., 1997, 1998, 2000; Le Huërou et al., 1998; Zabielski et al., 1998). Plasma PP shows a biphasic pattern, a transient peak related to suckling is followed by a long lasting inhibition (Zabielski et al., 1998). Therefore, the post feeding changes in secretin and PP are opposite to those observed during the first day of life (Guilloteau et al., 1992a). Perhaps vagal stimulation resulting from the meal is of shorter duration in the neonatal animal since Bloom et al. (1978) found a post-feeding increase of PP only during the first $20 \mathrm{~min}$. Similarly, the increase of the PP plasma concentration from $15 \mathrm{~min}$ before to $30 \mathrm{~min}$ after the meal (Duvaux et al., 1992) could be related to the prefeeding increase of pancreatic secretion (a classical Pavlovian cephalic phase of secretion) which is not observed when the meal is given unexpectedly (Le Dréan et al., 1999). Secretin release is triggered when the duodenal $\mathrm{pH}$ drops below 4.5 units (Thompson et al., 1987). In a milk-fed calf, the $\mathrm{pH}$ value which is $2-3$ units before morning meal, increases up to 5-6 units immediately after feeding and returns below 4.5 units within 2-3 h after feeding (Guilloteau et al., 1975, 1979). These changes in $\mathrm{pH}$ elegantly explain low concentrations of plasma secretin recorded for about $1 \mathrm{~h}$ after feeding. Enhanced post-feeding concentrations of plasma gastrin and CCK are probably related to milk protein and fat load. The post-feeding changes of gastrin, CCK and somatostatin corroborate with the increases in gastric and biliary secretions. Indeed, gastric secretions are maximal within the first 2-3 post-feeding h (Guilloteau and Toullec, 1983; Guilloteau, 1986; Guilloteau et al., unpublished). Similarly, the secretion of biliary salts (Debarre et al., 1979) appears to follow a pattern similar to that of plasma CCK (Le Dréan et al., 1997).

Taking together the results of the bibliography and our own, it is interesting to detail the mechanisms involved, including in particular the gut regulatory peptides, in a preruminant calf fed milk replacer based on skim milk powder. First of all, in these calves clear-cut ultradian and circadian rhythms are present, and meal ingestion is the main factor that induces the changes in the pattern of plasma gut regulatory peptide concentrations (Accarry et al., 1983; Ruckebush et al., 1983; Guilloteau, 1986; Guilloteau et al., unpublished). The ultradian pattern of plasma secretin concentrations corroborates with that of the flow of pancreatic juice, and a similar relation was reported for gastrin and CCK on one hand, and pancreatic protein and enzyme secretions on the other (Le Dréan et al., 1997, 1998; Figure 4). In fact, intravenous administration of secretin stimulates pancreatic juice flow while that of CCK and gastrin increases pancreatic protein and enzyme secretions (Davicco et al., 1980; Pierzynowski et al., 1991; Zabielski et al., 1992, 1995). In addition, short lasting hourly rhythms associated with the duodenal migrating myoelectric complex (MMC) have been reported for 
A1

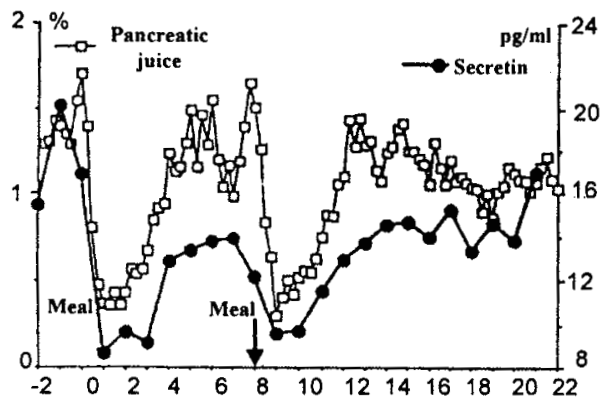

A2
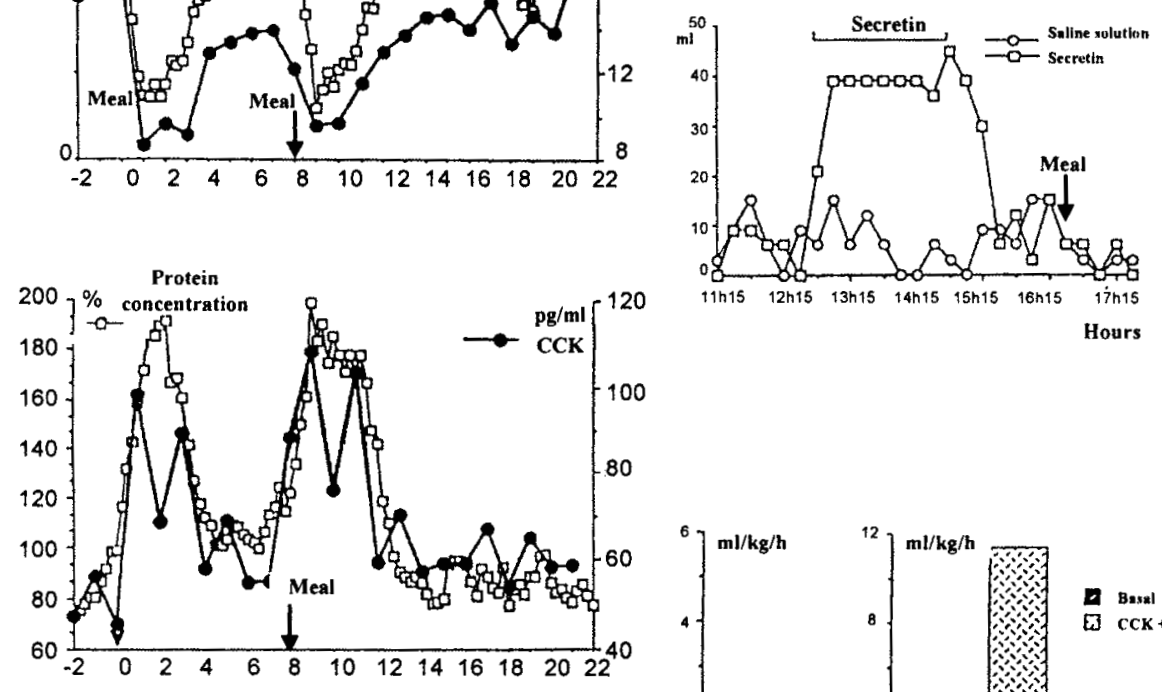

B

C
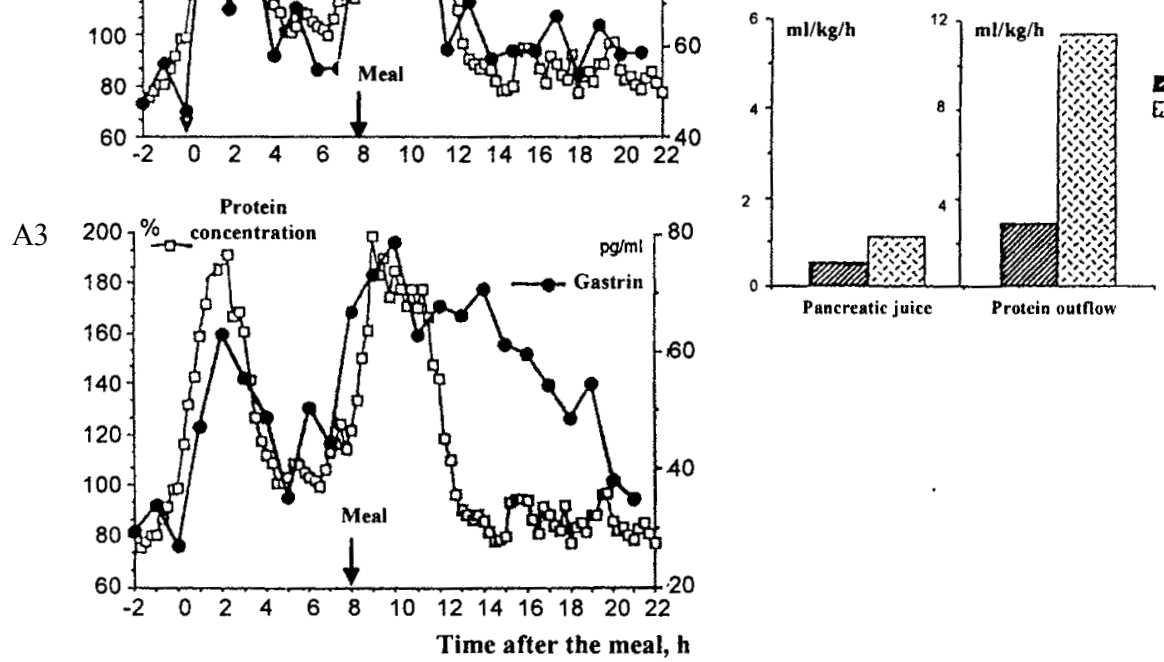

Figure 4. Circadian patterns of plasma concentrations of secretin, CCK and gastrin and secretion of pancreatic juice (A1, A2 and A3). Effect of intravenous infusions of secretin alone (B), and a combination of secretin $+\mathrm{CCK}-8$ bolus $(\mathrm{C})$ on the secretion of pancreatic juice. A1, A2 and A3: values of plasma gut regulatory peptide concentrations are given in $\mathrm{pg} / \mathrm{ml}$; the values of pancreatic juice are the percentage of the total collection during the whole day and those of protein concentrations are the percentage of the mean concentration during the whole day. B: values are expressed as $\mathrm{ml} / 15 \mathrm{~min}$. $\mathrm{C}$ : values are given as $\mathrm{mg} / \mathrm{kg}$ liveweight/h (adapted from Pierzynowski et al., 1991; Le Déan et al., 1998, 1999; Guilloteau et al., unpublished) 
secretin, PP, motilin, CCK and somatostatin (but not gastrin) in preruminant calves (Zabielski et al., 1994, 1998).

Secondly, the presence of the CCK/gastrin family receptors was shown in the pancreas (Le Meuth et al., 1993) and intestinal mucosa (Zabielski et al., 2002). The $\mathrm{CCK}_{1}$ receptor mediates the effects of CCK and gastrin, whist the receptor to gut peptide type 2 or B $\left(\mathrm{CCK}_{2}\right)$ receptor mediates only that of gastrin. Also, the presence of the secretin/VIP family receptors was evidenced in the pancreas (Le Meuth et al., 1993; Le Meuth-Metzinger et al., 2005). The VIP-2 receptor mediates the effects of pituitary adenylate cyclase-activiting polypeptide (PACAP) and helodermine (PACAP-38 $>$ helodermine $>$ PACAP-27) and the secretin receptor is specific for the corresponding peptide.

Thirdly, intravenous infusions in a physiological range of these gut regulatory peptides can stimulate the secretion of pancreatic juice rich in fluid and bicarbonates for the secretin/VIP family and juice rich in enzymes for the CCK/gastrin family (Davicco, 1978; Pierzynowski et al., 1991; Le Dréan et al., 1997, 1998, 1999, 2000; Zabielski et al., 1992, 1994; Figure 3). During the interdigestive periods, CCK and gastrin stimulate pancreatic exocrine secretion and these effects are partly mediated by the $\mathrm{CCK}_{2}$ receptor. Although $\mathrm{CCK}_{1}$ receptors in the pancreas tissue are not predominant, they seem to play a major role in the response of pancreatic exocrine secretion to intravenous CCK (Le Dréan et al., 1999). During response to feeding, $\mathrm{CCK}_{1}$ receptors, but not $\mathrm{CCK}_{2}$ receptors, are involved (Le Dréan et al., 2000). In using ElasCCK ${ }_{2}$ mice acinar cells as a model, Desbois et al. (1999) have shown that the $\mathrm{CCK}_{2}$ receptors mediate enzyme release but are more efficient in stimulating enzyme synthesis. Moreover, $\mathrm{CCK}_{2}$ receptor-stimulated protein synthesis likely results from enhancement of mRNA translation and involves phosphatidyl inositol 3-kinase and p70 S6 kinase.

In the preruminant calf, the replacement of casein by whey protein in the diet affects blood molecular forms, splanchnic release, hepatic clearance and outputs from the liver of most gut regulatory peptides (Guilloteau, 1986; Guilloteau et al., 1988, 1994, 1997; Guilloteau et al., unpublished). Total replacement of skim milk proteins by soyabean and fish proteins led to a decrease in the basal plasma concentrations of secretin and GIP. One $h$ after the meal the GIP concentration was still reduced, whilst that of CCK increased (Guilloteau et al., 1986a). Similar trends were observed for secretin and CCK when fish protein hydrolysate was used as the protein source in milk replacer (Guilloteau et al., 1984b, 1986b; Le Huërou-Luron et al., 1998; Zabielski et al., 1998). The postprandial release of CCK, gastrin and secretin is sensitive to dietary proteins and could be responsible for changes in the composition of pancreatic juice proteins (Le Dréan at al., 1998). These variations in plasma concentrations of gut regulatory peptides largely depend on the protein's ability to coagulate in the abomasum (an important determinant of gastric emptying) and chemical structure of protein, thus the 
susceptibility to pepsin hydrolysis. However, with soyabean proteins the resulting stimulation of pancreatic trypsin activity is insufficient to increase the digestibility of soyabean nitrogen to a level similar to that of cow milk, as was shown recently (Guilloteau and Zabielski, 2005).

After progressive weaning (between 28 and 56 day) of calves, the basal plasma concentration of several gut regulatory peptides is definitively altered. Gastrin, CCK, PP and GIP are higher, whilst secretin and somatostatin are lower in the weaned calf than in the exclusively milk-fed calf. This could result from the fact that before feeding, the upper GIT is more empty in the latter than in the former. These modifications in plasma gut regulatory peptide concentrations could be related to the higher tissue content of most of the digestive enzymes (Le Huërou et al., 1992; Le Huërou-Luron et al., 1992; Figure 3). In this way, the role of PP and GIP is questionable since their concentrations dramatically increase in similar proportion to that observed for several characteristic abomasal and pancreatic enzymes of the ruminant stage (pepsin, lysosyme, elastase I, carboxipeptidase $\mathrm{A}$ and $\mathrm{B}$, and ribonuclease) (Guilloteau et al., 2005). In fact, as observed in preruminants, intravenous infusion of secretin stimulates pancreatic juice flow, while that of CCK and gastrin increases pancreatic protein and enzyme secretion (Harada et al., 1986; Kato et al., 1991). Feeding has no effect on the plasma concentrations of these gut regulatory peptides in weaned calves except for GIP, which rise (Guilloteau et al., 1992b; Toullec et al., 1992; Le Dréan et al., 1997) as well as on pancreatic exocrine secretions (Le Dréan et al., 1997) in contrast to the results obtained in milk-fed calves. The lack of post-feeding changes could be explained by the more regular stomach distension and flow rate of the digesta, as well as the stability of the duodenal content $\mathrm{pH}$, which is about 2.7 units. Thus, the existence of the ruminal phase, in addition to the classical cephalic, gastric and intestinal digestive phases observed in monogastric animals (and in part in preruminant calves) and in relation to volatile fatty acids (Kato et al., 1991; Croom et al., 1992), is questionable.

\section{GUT REGULATORY PEPTIDES AND DIGESTIVE MOTILITY}

The GIT of simple-stomached animals manifests rhythmic activities of 1-2 $\mathrm{h}$ duration (Szurszewski, 1969). These activities concern GI motility and digestive secretions, including endocrine secretions (Konturek et al., 1986; Zabielski et al., 1998). The GI motility and periodic activity of the exocrine pancreas of young ruminants have been described in detail previously (Zabielski and Naruse, 1999; Zabielski et al., 1993, 1997, 1998, 2001). In brief, the small intestine MMC consists of three distinct phases in the calf: the no spiking activity (NSA) phase, irregular spiking activity (ISA) phase, and regular spiking activity (RSA) phase (Dardillat and 
Ruckebush, 1973; Dardillat and Marrero, 1977; Dardillat and Bueno, 1979). The NSA phase is electromyo-graphically characterized as a period of quiescence (no spike bursts, slow waves only) that results in a lack of mixing and propulsive contractions and no digesta flow in the examined segment of the intestine. During the ISA phase, the frequency and amplitude of spike bursts increase in an irregular manner, reaching their maxima during the RSA phase. The mixing contractions dominate during the early ISA phase, as do the propulsive contractions during the last ISA and RSA phases. The GIT secretory activities coincide with the phases of duodenal MMC, e.g., the secretion of pancreatic juice is low during the NSA phase and high during the ISA phase (Zabielski et al., 1993). In contrast to single-stomached animals in which feeding disrupts the periodic activity for several hours, in preruminant and preruminant calves the periodic activity of the abomasum, small intestine and pancreas is transiently influenced by feed (Zabielski et al., 1997, 1998). It has therefore been suggested that the periodic activity of the GIT in ruminants is actively involved in the digestive processes. However, most of the studies in cattle and sheep published so far, report either results obtained by simultaneously investigating the rhythmic changes in the concentrations of plasma gut regulatory peptides and gastrointestinal motility, or the effects of exogenous gut regulatory peptides on GI motility. Studies involving digestive productions are scarce and almost exclusively concern pancreatic secretion (Zabielski and Naruse, 1999).

\section{Gut regulatory peptides and small intestinal motility}

The spontaneous contractile activity of smooth muscles from the ovine complex stomach undergoes appreciable ontogenetic development. It appears first in the abomasum at the end of the 2 gestational month. The contractile activity of the abomasum gradually increases from a non-propagating low amplitude nonrhythmic pattern during the first half of pregnancy to RSA alternated with NSA phases near term. At 0.6 of term, the reticulum manifests stable spontaneous phasic contractile activity that disappears after delivery, while the rumen manifests no regular contractile activity before or after birth. In the foetal lamb, the subsequent development of the motor activity consists of an increase in slow-wave frequency as a prerequisite for the duration of the spiking activity and increases in aboral propagation. Finally, the myoelectric phenomena of the GIT recorded a few days before birth and in the unfed newborn lamb and calf, resemble the MMC of adults, though of considerably shorter cycle duration (Ruckebush et al., 1983). This evolution during foetal life could be in relation to the variations observed in plasma gut regulatory peptides by Guilloteau et al. (1998a), including plasma leptin, since this peptide could have a role in gut motility as well as in intestinal absorption (Margetic et al., 2002). 
After birth, the first meal induces a pattern of continuous spiking activity at the expense of the periods of quiescence and RSA, and the myoelectric activity of the GIT from postnatal day 4 to 6 onward becomes well organized and except for the duration of the MMC cycle, it does not change (Ruckebush et al., 1983 and personal communication). This is consistent with the increase of gastrin and CCK and decline in motilin (Guilloteau et al., 1992b). During the first week after birth: 1. progressive development of the motor responses to feeding occurs; these responses consist of a hyperactivity of the whole small intestine immediately after and even during feeding (Ruckebush et al., 1983), 2. pancreatic secretion increases (Biernat et al., 1999), and 3. plasma levels of motilin, CCK, secretin and PP increase (Guilloteau et al., 1992b).

In preruminant calves fed with milk replacer based on skim milk powder and during the interdigestive period, the myoelectricity of the GIT is well characterized (Dardillat and Morerro, 1977; and, see above) as are the levels of gut regulatory peptides. Thus, periodic fluctuations of several gut regulatory peptides in concert with MMC were observed (Zabielski et al., 1998; Figure 5).

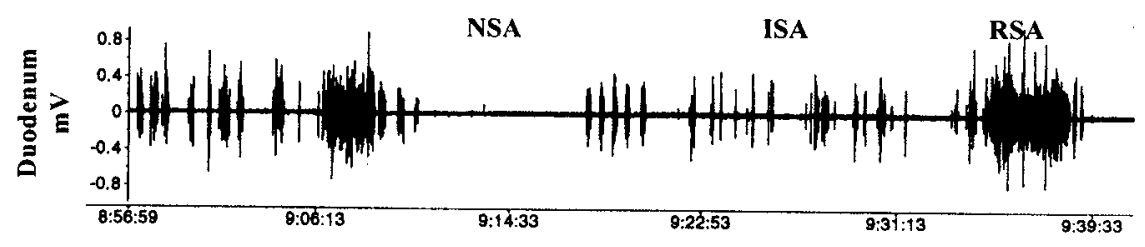

\begin{tabular}{lcccc}
\hline $\begin{array}{l}\text { Gut regulatory } \\
\text { peptide }\end{array}$ & NSA & Early ISA & Late ISA & RSA \\
\hline PP & $200 \pm 30^{\mathrm{a}}$ & $360 \pm 25^{\mathrm{b}}$ & $320 \pm 20^{\mathrm{bc}}$ & $310 \pm 30^{\mathrm{c}}$ \\
Motilin & $28 \pm 6^{\mathrm{a}}$ & $29 \pm 7^{\mathrm{a}}$ & $50 \pm 7^{\mathrm{b}}$ & $35 \pm 6^{\mathrm{a}}$ \\
Secretin & $19 \pm 2^{\mathrm{a}}$ & $26 \pm 3^{\mathrm{b}}$ & $30 \pm 3^{\mathrm{b}}$ & $27 \pm 3^{\mathrm{b}}$ \\
CCK & $28 \pm 2^{\mathrm{a}}$ & $46 \pm 4^{\mathrm{b}}$ & $45 \pm 5^{\mathrm{b}}$ & $38 \pm 5^{\mathrm{c}}$ \\
Gastrin & $37 \pm 5$ & $25 \pm 5$ & $29 \pm 4$ & $32 \pm 4$ \\
Somatostatin & $43 \pm 7^{\mathrm{a}}$ & $58 \pm 4^{\mathrm{b}}$ & $66 \pm 5^{\mathrm{c}}$ & $50 \pm 4^{\mathrm{b}}$ \\
\hline
\end{tabular}

Figure 5. Temporal synchroneity between the duodenal migrating motor complex (MMC) and plasma profile of gut regulatory peptides $(\mathrm{pg} / \mathrm{ml})$ in preruminant calves fed with milk replacer based on skim milk (adapted from Zabielski et al., 1998). Plasma samples were collected during the phase of no spiking activity (NSA), early and late irregular spiking activity (ISA), and regular spiking activity (RSA) of the MMC in the duodenum. Mean and SEM; different letters in superscript indicate statistical differences $(\mathrm{P}<0.05)$ 
Moreover, the motilin concentration peaks before the RSA phase and drops just after it; similarly, the somatostatin concentrations are higher during the ISA phase than during RSA (Duvaux, 1989). After feeding, the fluctuations in plasma gut regulatory peptide concentrations disappear for a few hours, whereas the MMC cycles do not. In addition, the periodic pancreatic cycles are disrupted by feeding only for about 1-2 h, and reappear thereafter, the periodic fluctuations in secretion start together with the recovery of the duodenal MMC (Zabielski et al., 1993, 1998). Moreover, intravenous continuous infusion of CCK and motilin, which increase their plasma concentrations several-fold (and apparently disrupt their physiological fluctuations in the peripheral blood) do not abolish duodenal or pancreatic cycles (Zabielski et al., 1995). In the same study, administration of exogenous secretin disrupted the duodenal MMC but not the pancreatic cycles. These observations could suggest that the observed fluctuations of plasma gut regulatory peptides are not the cause of GI motor or secretory cycles.

Feeding with milk replacer based on a fish protein concentrate markedly disturbs both the periodic fluctuations of several plasma gut regulatory peptides as well as small intestinal motility. The duration of each MMC cycle is shorter on a fish or soyabean diet than that on milk protein diet (Duvaux, 1989; Zabielski et al., 1998). In this case, the lack of preprandial and early postprandial secretin cycles in calves fed on non-clotting protein support the idea that fluctuations of plasma secretin are secondary and may be related to the changes in duodenal $\mathrm{pH}$. With milk or fish proteins, fluctuations in plasma CCK concentrations are shown to be in phase with the duodenal MMC (Zabielski et al., 1998); by contrast these plasma CCK concentration oscillations were not observed by Zabielski et al. (1994) who attributed this fact to the presence of soyabean protein in milk formula.

\section{Gut regulatory peptides, digestive secretion and small intestinal motility}

In preruminant and ruminant calves, distinct periodic fluctuations in pancreatic juice secretion in phase with duodenal MMC and cycles in plasma of some gut regulatory peptides are recorded. The peak of pancreatic secretion coincides with the late ISA phase in the duodenum and the nadir with the NSA (Zabielski et al., 1993, 1997, 1998). The concentration of secretin in plasma is 1.4 times higher during the ISA phase than during NSA (Zabielski et al., 1994). This pattern is not observed in non-ruminant species. Periodic fluctuations of PP and motilin associated with the secretory and motor events of the upper GIT are well known in monogastric animals (Walsh and Docray, 1994) but questioned in sheep in regard to motilin (Plaza et al., 1996). The intravenous administration of motilin in a physiological range results in an increase of the frequency of pancreatic and duodenal cycles. Exogenous secretin lengthened duodenal but not 
pancreatic cycles resulting in a loss of synchronization (Zabielski et al., 1995). Both intraduodenal and intravenous infusions of CCK-8 and gastrin resulted in marked pancreatic secretory responses, but did not affect the duration of MMC in the duodenum (Zabielski et al., 2004). From these studies it seems that the fluctuations in gut regulatory peptides are rather the consequences of than the cycle-makers of the periodic activity of the stomach and small intestine. Nutrients leaving the abomasum can induce the fluctuations of certain gut peptides, for instance abomasal acids induce secretin, proteins induce CCK and gastrin. The temporarily elevated plasma gut regulatory peptides may transiently enhance digestive secretions, local blood flow and absorption thereby adjusting current GI digestive functions to actual needs.

\section{CONCLUSIONS}

The enteroendocrine cells dispersed in the GIT form the largest regulatory system in the body with regard to the magnitude and the multitude of peptides it produces. The extent of this unique system gives some indications of how important it may be in controlling the function of the gut, however, we still do not know all of the components involved. As an example, during the last decade several novel gut regulatory peptides such as leptin and ghrelin have been discovered and there may be more not yet uncovered. To our knowledge, the research concerning the role of the last two mentioned peptides in gastrointestinal tract development, motility and secretion in farm animals is very limited.

Increasing knowledge about the biological functions and mechanisms of gut regulatory peptide actions could help in managing the growth and maturation of the gastrointestinal tract and in better optimizing digestive motility and productions. It is particularly important in the young to help them to better pass through the critical periods like the neonatal and weaning stages. Complementary work must be done in this area, as was suggested by Guilloteau et al. (2002). Moreover, besides the gut regulatory peptides, other ways need to be explored and integrated to suggest a common overview of the mechanisms involved, as was recently done for pancreatic secretion (Konturek et al., 2003). The aim of the synthesis of the studies in these complementary areas must have an integrative objective and try to relate the physiological status of the molecules, cells, tissues, organs, systems, functions and finally the whole body in its environment. It is also necessary to maintain good relations between the components of the diet and the nutrients produced at different levels of the GIT. 


\section{ACKNOWLEDGEMENT}

The authors would like to thank J. Chevalier who kindly agreed to produce the illustrations for this review and to Annie Barbeau for collecting the bibliographical information.

\section{REFERENCES}

Accary J.P., Guilloteau P., Toullec R., Chayvialle J.A., Dubrasquet M., Reinberg A., 1983. Circadian changes and ultradian rhythms in plasma gastrin of preruminant calves during fast and after feeding. Chronobiologia 10, 105

Avila C.G., Harding R., Young I.R., Robinson P.M., 1989. The role of gastrin in the development of the gastrointestinal tract in fetal sheep. Quart. J. Exp. Physiol. 74, 169-180

Basedovsky H.O.,Rey A.D., 1996. Immune-neuro-endocrine interactions: facts and hypotheses. Endocrine Rev. 17, 64-102

Bell A.W., Cranwell P.D., Hansky J., 1984. Plasma gastrin in the fetal and neonatal lamb, and the pregnant and lactating ewe. Can. J. Anim. Sci. 64, Suppl., 97-99

Biernat M., 2002. Factors controlling growth and maturation of the porcine small intestival structure and function in an early postnatal period (in Polish). PhD. Thests. The Kielanowski Institute of Animal Physiology and Nutrition, Polish Academy of Sciences, Jabłonna (Poland)

Biernat M., Zabielski R., Sysa P., Sosak-Swiderska B., Le Huërou-Luron I., Guilloteau P., 1999. Small intestinal and pancreas microstructures are modified by an intraduodenal CCK-A receptor antagonist administration in neonatal calves. Regul. Peptides 85, 77-85

Blattler U., Hammon H.M., Morel C., Philipona C., Rauprich A., Romé V., Le Huërou-Luron I., Guilloteau P., Blum J.W., 2001. Feeding colostrum, its composition and feeding duration variably modify proliferation and morphology of the intestine and digestive enzyme activities of neonatal calves. J. Nutr. 131, 1256-1263

Bloom J.W., 2005a. Bovine gut development. In: P. Garnsworthy (Editor). Rearing the Modern Dairy Heifer. Nottingham University Press, pp. 31-52

Bloom J.W., 2005b. Nutritional, metabolic and endocrine status of neonatal calves. In: J.W. Blum (Editor). Milk-Fed Farm and Companion Animals: Basic Aspects and Practice for the Future (in press)

Bloom J.W., Zbinden Y., Hammon H., Chilliard Y., 2005. Plasma leptin in milk-fed calves. In: J.W. Blum (Editor). Milk-Fed Farm and Companion Animals: Basic Aspects and Practice for the Future (in press)

Bloom S.R., Edouards A.V., Hardy R.N., 1978. The role of autonomic nervous system in the control of pancreatic endocrine responses to milk ingestion in the calf. J. Physiol. 280, 37-53

Bloom S.R., Polak J.M., 1981. Gut Hormones. Churchill Livingstone, London

Brameld J.M., 2005. Physiology of growth. In: P. Garnsworthy (Editor). Rearing the Modern Dairy Heifer. Nottingham University Press, pp. 13-30

Campana W.M., Braumrucker C.R., 1995. Hormones and growth factors in bovine milk. In: G.J. Jensen (Editor). Handbook of Milk Composition. Academic Press, New York, pp. 476-494

Conn P.M., Goodman H.M., 1998. Handbook of Physiology, Sect. 7: The Endocrine System, Vol. 1. Cellular Endocrinology. Oxford University Press, New York, Oxford

Croom Jr. W.J., Bull L.S., Taylor I.L., 1992. Regulation of pancreatic exocrine secretion in ruminants. A review. J. Nutr. 122, 191-202 
Dardillat C., Bueno L., 1979. Analysis of the propagation of spike burst potentials in calf. Ann. Rech. Vét. 10, 491-493

Dardillat C., Marrero E., 1977. Electromyographical analysis of preruminant calf intestine. Relation between migrating activity front and transit time (in French). Ann. Biol. Anim. Bioch. Biophys. $17,523-550$

Dardillat C., Ruckebush Y., 1973. Functional characteristics of the gastroduodenal junction of the newborn calf (in French). Ann. Rech. Vét. 4, 31-56

Davicco M.J., 1978. Regulation of exocrine pancreatic secretion in young calf (in French). PhD. Thesis, Université de Clemont II

Davicco M.J., Lefaivre J., Barley J.P., 1980. The endocrine regulation of exocrine pancreas in preruminant milk-fed calves. Ann. Rech. Vét. 11, 123-132

Debarre M., Thivend P., Lefaivre J., Toullec R., 1979. Biliary secretion in preruminant calves. Ann. Rech. Vét. 10, 425-427

Dembiński A., Warzecha Z., Ceranowicz P., Dembiński M., Kabat K., Konturek S. J., Kownacki P., Hladki W., Pawlik W.W., 2004. Influence of central and peripheral administration of pancreatic polipeptide on gastric mucosa growth. J. Physiol. Pharmacol. 55, 223-237

Desbois C., Le Huërou-Luron I., Dufresne M., Estival A., Clerc P., Romé V., Clemente F., Guilloteau P., Fourmy D., 1999. The CCK-B/gastrin receptor is coupled to the regulation of enzyme secretion, protein synthesis, and p70 S6 kinase activity in acinar cells from ElasCCKB transgenic mice. Eur. J. Biochem. 266, 1003-1010

Duvaux C., 1989. Mechanisms involved in preruminant calf (and piglet) fed an diet based on antigenic soya proteins (in French). PhD. Thesis, ENSA Rennes, pp.131

Duvaux C., Guilloteau P., Toullec R., Chayvialle J.A., Bernard C., Sissons J.W., 1992. Taux circulants de gastrine et de polypeptide pancréatique (PP) chez des veaux préruminants recevant des laits de remplacement contenant des protéines de lait ou de soja. Ann. Zootech. 41, 127-128

Gestin M., Le Huërou-Luron I., Peiniau J., Thioulouse E., Desbois C., Le Dréan G., Feldman D., Aumaitre A., Guilloteau P., 1997. Method of measurement of pancreatic elastase II activity and postnatal development of proteases in human duodenal juice and bovine and porcine pancreatic tissue. Digest. Dis. Sci. 42, 1302-1311

Glass G.B.J., 1980. Gastrointestinal Hormones. Raven Press, New York

Greely Jr. G.H., 1999. Gastrointestinal Endocrinology. Humana Press, Totowa, New Jersey

Grongnet J. F., Patureau-Mirand P., Toullec R., Prugnaud J., 1981. Utilisation of milk and whey proteins by the young preruminant calf. Influence of age and whey protein denaturation (in French). Ann. Zootech. 30, 443-464

Guilloteau P., 1986. Digestion of proteins in preruminant calf (in French). PhD. Thesis, Université Pierre et Marie Curie, Paris, pp. 224

Guilloteau P., Biernat M., Wolinski J., Zabielski R., 2002. Gut regulatory peptides and hormones of the small intestine. In: R. Zabielski, B. Gregory, B. Westrom (Editors). Biology of the Intestine in Growing Animals. Elsevier Science, Amsterdam, pp. 271-324

Guilloteau P., Chayvialle J.A., Durand D., Bernard C., Toullec R., Mouats A., Bauchart D.,1988. Gastroenteropancreatic production and hepatic clearance of gastrin and somatostatin in preruminant calf fed milk replacers based on milk or whey proteins. Reprod. Nutr. Dévelop. 28, Suppl.1, 163-164

Guilloteau P., Chayvialle J.A., Le Huërou-Luron I., Mouats A., Durand D., Bernard C., Bauchart D., Toullec R., 1994. Molecular forms, gastro-entero-pancreatic production and hepatic clearance of gastrin and somatostatin in the preruminant calf. Effect of dietary protein. Proc. Soc. Nutr. Physiol. 3, 294 
Guilloteau P., Chayvialle J.A., Toullec R., Grongnet J.F., Bernard C., 1992a. Early-life patterns of plasma gut regulatory peptide levels in calves: Effects of the first meals. Biol. Neonate 61, 103-109

Guilloteau P., Chayvialle J.A., Toullec R., Grongnet J.F., Dardillat C., Bernard C., 1986b. Evolution du taux plasmatique de CCK avec l'âge et le régime alimentaire chez le jeune veau. Reprod. Nutr. Dévelop. 26, 377-378

Guilloteau P., Corring T., Chayvialle J.A., Bernard C., Sissons J.W., Toullec R., 1986a. Effect of soya protein on digestive enzymes, gut hormone and anti-soya antibody plasma levels in the preruminant calf. Reprod. Nutr. Dévelop. 26, 717-728

Guilloteau P., Corring T., Garnot P., Martin P., Toullec R., Durand G., 1983. Effect of age and weaning on enzyme activities of abomasum and pancreas of the lamb. J. Dairy Sci. 66, 2373-2385

Guilloteau P., Corring T., Toullec R., Robelin J., 1984a. Enzyme potentialities of the abomasum and pancreas of the calf. I - Effect of age in the preruminant. Reprod. Nutr. Dévelop. 24, 315-325

Guilloteau P., Corring T., Toullec R., Villette Y., Robelin J., 1985. Abomasum and pancreas enzymes in the newborn ruminant : effects of species, breed, sex and weight. Nutr. Rep. Int. 31, 1231-1236

Guilloteau P., Le Huërou-Luron I., Chayvialle J.A., Mouats A., Bernard C., Cuber J.C., Burton J., Puigserver A., Toullec R., 1992b. Plasma and tissue levels of digestive regulatory peptides during postnatal development and weaning in the calf. Reprod. Nutr. Develop. 32, 285-296

Guilloteau P., Le Huërou-Luron I., Chayvialle J.A., Toullec R., Zabielski R., Blum J.W., 1997. Gut regulatory peptides in young cattle and sheep. J. Vet. Med. A, 44, 1-23

Guilloteau P., Le Huërou-Luron I., Le Dréan G., Gestin M., Philouze-Romé V., Artiaga A., Bernard C., Chayvialle J.A., 1998a. Gut regulatory peptide levels in bovine fetuses and their dams between the 3rd and 9th months of gestation. Biol. Neonate 74, 430-438

Guilloteau P., Le Huërou-Luron I., Romé V., Plodari M., 1999. Nutrient absorption is related to quantity of pancreatic enzyme secretion : preliminary results. S. Afr. J. Anim. Sci. 29, 241-242

Guilloteau P., Le Huërou-Luron I., Tallec M., Beaufils M., Toullec R., 1998b. Effect of age and weaning on development of digestive tract of lambs. In: J.W. Blum, T. Elsasser, P. Guilloteau (Editors). Proceedings of Symposium on Growth in Ruminants: Basic Aspects, Theory and Practice for the Future. Berne (Switzerland), p. 287

Guilloteau P., Paruelle J.L., Toullec R., Mathieu C.M., 1975. Utilization of proteins by the preruminant fattening calf. III - Gastric emptying as affected by the substitution of milk protein by fish protein (in French). Ann. Zootech. 24, 243-253

Guilloteau P., Toullec R., 1983. Circadian changes in the abomasal secretions of the preruminant calf. Reprod. Nutr. Dévelop. 23, 967-977

Guilloteau P., Toullec R., Chayvialle J.A., Grongnet J.F., 1984b. Early-life pattern of plasma gastro-enteropancreatic hormones in calves. Vth International Symposium on Gastrointestinal Hormones, Rochester (USA)

Guilloteau P., Toullec R., Garnot P., Martin P., Brule G., 1980. Influence de l'âge sur les sécrétions de suc gastrique et d'électrolytes chez le veau préruminant. Reprod. Nutr. Dévelop. 20, 12791284

Guilloteau P., Toullec R., Sauvant D., Paruelle J.L., 1979. Utilization of proteins by the preruminant calf. VII - Influence of replacement of skim milk powder by soyabean or field bean protein concentrates on gastric emptying (in French). Ann. Zootech. 28, 1-17

Guilloteau P., Zabielski R., 2005. Digestive secretions in preruminant and ruminant calves and some aspects of their regulation, In: P. Garnsworthy (Editor). Rearing the Modern Dairy Heifer. Nottingham University Press, pp. 159-190

Guilloteau P., Zabielski R., Blum J.W., 2005. Digestive tract development in neonatal and young ruminants and consequence. In: J.W. Blum (Editor). Milk-Fed Farm and Companion Animals: Basic Aspects and Practice for the Future (in press) 
Harada E., Niiyama M., Syuto B., 1984. Hepatic bile and pancreatic exocrine secretions evoked by gastrointestinal peptides in sheep. Comp. Biochem. Physiol. Pt. A 85, 729-734

Heinz-Erian P., Deutsch K., Granditsch G., 1992. Regulatory gut peptides in pediatric gastroenterology and nutrition. $6^{\text {th }}$ Annual Meeting og the GPGE, Goldegg/Salzburg. Karger, Basel

Kasaki T.R., 1994. Physiologic mechanisms of adaptation in the fetal calf at birth. Vet. Clin. N. Amer. Food Anim. Pr. 10, 127-136

Kato S., Katho K., Barej W., 1991. Regulation of exocrine pancreatic secretion in ruminant. In: T. Tsuda, Y. Sasaki, R. Kawashima (Editors). Physiological Aspects of Digestion and Metabolism in Ruminants. Academic Press, San Diego, California, pp. 89-109

Koldovsky O., 1989. Search for a role of milk-born biologically active peptides for the suckling. J. Nutr. 119, 1543-1551

Konturek S.J., Thor P., Bilski J., Bielanski W., Laskiewicz J., 1986. Relationships between duodenal motility and pancreatic secretion in fasted and fed dogs. Amer. J. Physiol. 250, G570-G574

Konturek S.J., Zabielski R., Konturek J.W., Czarnecki J., 2003. Neuroendocrinology of the pancreas; role of brai-gut axis in pancreatic secretion. Eur. J. Pharmacol. 481, 1-14

Le Dréan G., Le Huërou-Luron I., Chayvialle J.A., Philouze-Romé V., Gestin M., Bernard C., Toullec R., Guilloteau P., 1997. Kinetics of pancreatic exocrine secretion and plasma gut regulatory peptide release in response to feeding in preruminant and ruminant calves. Comp. Biochem. Physiol. Pt. A 117, 245-255

Le Dréan G., Le Huërou-Luron I., Gestin M., Desbois C., Romé V., Bernard C., Dufresne M., Moroder L., Gully D., Chayvialle J.A., Fourmy D., Guilloteau P., 1999. Exogenous CCK and gastrin stimulate pancreatic exocrine secretion via CCK-A but also CCK-B/gastrin receptors in the calf. Pflügers Arch. - Eur. J. Physiol. 438, 86-93

Le Dréan G., Le Huërou-Luron I., Gestin M., Romé V., Bernard C., Chayvialle J.A., Fourmy D., Guilloteau P., 2000. Pancreatic secretory response to feeding in the calf : CCK-A receptors, but not CCK-B/gastrin receptors are involved. Can. J. Physiol. Pharmacol. 78, 813-819

Le Dréan G., Le Huërou-Luron I., Gestin M., Romé V., Plodari M., Bernard C., Chayvialle J.A., Guilloteau P., 1998. Comparison of the kinetics of pancreatic secretion and gut regulatory peptides in the plasma of preruminant calf fed milk or soyabean protein. J. Dairy Sci. 81, 1313-1321

Le Huërou I., Guilloteau P., Wicker C., Mouats A., Chayvialle J.A., Bernard C., Burton J., Toullec R., Puigserver A., 1992. Activity distribution of seven digestive enzymes along small intestine in calves during development and weaning. Digest. Dis. Sci. 37, 40-46

Le Huërou-Luron I., Gestin M., Le Dréan G., Romé V., Bernard C., Chayvialle J.A., Guilloteau P., 1998. Source of dietary protein influences kinetics of plasma gut regulatory peptide concentration in response to feeding in preruminant calves. Comp. Biochem. Physiol. Pt. A 119, 817-824

Le Huërou-Luron I., Guilloteau P., Wicker-Planquart C., Chayvialle J.A., Burton J., Mouats A., Toullec R., Puigserver A., 1992. Gastric and pancreatic enzyme activities and their relationship with some gut regulatory peptides during postnatal development and weaning in the calf. J. Nutr. $122,1434-1445$

Le Meuth V., Philouze-Rome V., Le Huërou-Luron I., Formal M., Vaysse N., Gespach C., Guilloteau P., Fourmy D., 1993. Differential expression of A- and B-subtypes of cholecystokinin/gastrin receptors in the developing calf pancreas. Endocrinology 133, 1182-1191

Le Meuth-Merzinger V., Philouze-Romé V., Merzinger L., Gespach C., Guilloteau P., 2005. Differential activation of adenylate cyclase by secretin and VIP receptors in the calf pancreas. Pancreas (in press)

Margetic S., Gazzola C., Pegg G.G., Hill R.A., 2002. Leptin: a review of its peripheral actions and interactions. Int. J. Obesity 26, 1407-1433 
Morisset J., Bourassa J., Tessier P., Lainé J., Lessard M., Romé V., Guilloteau P., 2003. Revisiting cholecystokinin control of pancreatic secretion in calf. Regul. Peptides 111,103-109

Mulvihill S.J., Stone M.M., Fonkalsrud E.W., Debas H.T., 1986. Trophic effect of amniotic fluid on fetal gastrointestinal development. J. Surg. Res. 40, 291-296

Oldham K.T., Thompson J.C., 1987. Ontogeny of gut peptides. In: J.C. Thompson, G.H. Greeley, P.L. Rayford, C.M. Townsend (Editors). Gastrointestinal Endocrinology. McGraw-Hill, New York, pp. 158-177

Pavaux Cl., 1977. Anatomical knowledge (in French). In : P. Mornet, J. Espinasse (Editors). Le Veau. Paris, Maloine s.a. Editeur, pp. 33-98

Pierzynowski S. G., Zabielski R., Weström B., Mikolajczyk M., Barej W., 1991. Development of the exocrine pancreatic function in chronically cannulated calves from the preweaning period up to early rumination. J. Anim. Physiol. Anim. Nutr. 65,165-172

Plaza M.A., Arruebo M.P., Murillo M.D., 1996. Involvement of somatostatin, bombezin and serotonin in the origin of the migrating myoelectric complex in sheep. Life Sci. 58, 2155-2165

Roy J.H.B., 1980. The Calf. $4^{\text {th }}$ Edition. Butterworths, London

Ruckebush Y., 1977. Digestive physiology. Digestion, absorption and metabolism of nutrients (in French). In : P. Mornet, J. Espinasse (Editors). Le Veau. Paris, Maloine s.a. Editeur, pp. 112-123

Ruckebush Y., Dardillat C., Guilloteau P., 1983. Development of digestive functions in the newborn ruminant. Ann. Rech. Vét. 14, 360-374

Rudloff S., Kunz C., 1997. Protein and nonprotein nitrogen components in human milk, bovine milk, and infant formula: quantitative and qualitative aspects in infant nutrition. J. Pediat. Gastroenterol. Nutr. 24, 328-344

Rudloff S., Lönnerdal B., 1992. Solubility and digestibility of milk proteins in infant formulas exposed to different heat treatments. J. Pediat. Gastroenterol. Nutr. 15, 25-33

Schneider D.A., Sayegh A.I., 2002. Gastrointestinal neuroendocrinology. Vet. Clin. Equine 18, 205-217

Shulkes A., Hardy K.J., 1982. Ontogeny of circulating gastrin of pancreatic polypeptide in the foetal sheep. Acta Endocrinol. 100, 565-572

Szurszewski J.H., 1969. A migrating electric complex of canine small intestine. Amer. J. Physiol. $217,1757-1763$

Thivend P., Toullec R., Guilloteau P., 1980. Digestive adaptation in the preruminant. In: Y. Ruckebusch, P. Thivend (Editors). Digestive Physiology and Metabolism in Ruminants. MTP Press, Lancaster, pp. 513-537

Thompson J.C., Greeley G.H., Rayford P.L., Townsend C.M., 1987. Gastrointestinal Endocrinology. McGraw-Hill, New York

Toofanian F., Hill F.W.G., Kidder D.E., 1974. The development of the intestinal disaccharidase activities in the fetal and newborn calf. Res. Vet. Sci. 16, 375-381

Toullec R., Chayvialle J.A., Guilloteau P., Bernard C., 1992. Early-life patterns of plasma gut regulatory peptide levels in calves. Effects of age, weaning and feeding. Comp. Biochem. Physiol. Pt. A 102, 203-209

Toullec R., Guilloteau P., 1989. Research into the digestive physiology of the milk-fed calf. In: E.J. Van Weerden, J. Huisman (Editors). Nutrition and Digestive Physiology of Monogastric Farm Animals. PUDOC, Wageningen, pp. 37-55

Toullec R., Guilloteau P., Le Huërou-Luron I., 1994. Postprandial development of endocrine intestine functions in young ruminants. In: W. Barej, R. Zabielski, P. Ostaszewski (Editors). The Developing of Digestive and Metabolic Processes in New Born and Growing Ruminants. Proceedings of Satellite Symposium to VIII ISRP, Warsaw (Poland), pp. 9-20 
Van Kessel A.G., Kochinski R.S., Laarveld B., 1993. Growth and serum thyroid hormone and insulin-like growth factor I responses to natural passive immunization against somatostatin in the lamb. Can. J. Anim. Sci. 73, 509-516

Van Kessel A.G., Laarveld B., 1994. Effect of passive immunization against somatostatin using a high-affinity antiserum on growth, IGF-1 and thyroid hormone levels in neonatal lambs reared under warm or cold environmental conditions. Can. J. Anim. Sci. 74, 23-27

Walsh J.H., 1994. Gastrin. In: J.H. Walsh, G.J. Docray (Editors). Gut Peptides, Biochemistry and Physiology. Raven Press, New York, pp. 76-121

Walsh J.H., Docray G.J., 1994. Gut Peptides. Biochemistry and Physiology. Raven Press, New York

Williams J.A., 2002. Receptor biology and intracellular regulatory mechanisms in pancreatic acinar secretion. Curr. Opin. Gastroen. 18, 529-535

Zabielski R., 1998. Regulatory peptides in milk, food, and in the gastrointestinal lumen of young animals and children. J. Anim. Feed Sci. 7, 65-78

Zabielski R., Dardillat C., Le Huërou-Luron I., Bernard C., Chayvialle J.A., Guilloteau P., 1998. Periodic fluctuations of gut regulatory peptides in phase with the duodenal migrating myoelectric complex in preruminant calf: effect of different sources of dietary protein. Brit. J. Nutr. 79, 287-296

Zabielski R., Kiela P., Leśniewska V., Krzemiński R., Mikołajczyk M., Barej W., 1997. Kinetics of pancreatic juice secretion in relation to duodenal migrating myoelectric complex in preruminant and ruminant calves feed twice daily. Brit. J. Nutr. 78, 427-442

Zabielski R., Kiela P., Onaga T., Mineo H., Gregory P. C., Kato S., 1995. Effect of neural blockades, gastrointestinal regulatory peptides and diversion of gastroduodenal contents on periodic pancreatic secretion in the preruminant calf. Can. J. Physiol. Pharmacol. 73, 1616-1624

Zabielski R., Morisset J., Podgurniak P., Romé V., Biernat M., Bernard C., Chayvialle J.A., Guilloteau P., 2002. Bovine pancreatic secretion in the first week of life : potential involvement of intestinal CCK receptors. Regul. Peptides 103, 94-104

Zabielski R., Naruse S., 1999. Neurohormonal regulation of the exocrine pancreas during postnatal development. In: S.G. Pierzynowski, R. Zabielski (Editors). Biology of the Pancreas in Growing Animals. Elsevier, Amsterdam, pp. 151-192

Zabielski R., Normand, V., Romé, V., Chayvialle, J.A., Guilloteau, P., 2003. The role of luminal gastrin in the regulation of pancreatic juice secretion in preruminant calves. Regul. Peptides $119,169-176$

Zabielski R., Onaga T., Mineo H., Kato S., 1993. Periodic fluctuations in pancreatic secretion and duodenal motility investigated in neonatal calves. Exp. Physiol. 78, 675-684

Zabielski R., Onaga T., Mineo H., Okine E., Kato S.. 1994. Pituitary adenylate cyclase-activating polypeptide (PACAP) stimulates exocrine pancreas in conscious preruminating calves. Comp. Biochem. Physiol. Pt. C 109, 93-99

Zabielski R., Pierzynowski S. G., 2001. Development and regulation of pancreatic juice secretion in cattle. State-of-the-art. J. Anim. Feed Sci. 10, 25-45

Zabielski R., Pierzynowski S. G., Podgurniak P., Sharma P., Barej W., 1992. Effect of secretin and cholecystokinin octapeptide (CCK8) on exocrine pancreas during cold vagal blockade in calves. J. Anim. Physiol. Anim. Nutr. 67, 173-180

Zabielski R., Terui Y., Onaga T., Mineo H., Kato S., 1994. Plasma secretin fluctuates in phase with periodic pancreatic secretion and the duodenal migrating myoelectric complex in calves. Res. Vet. Sci. 56, 332-337 


\section{STRESZCZENIE}

\section{Jelitowe peptydy regulacyjne jako mediatory wzrostu oraz rozwoju aktywności ruchowej i sekrecyjnej u młodych przeżuwaczy}

U ssaków rozwój tkanek płodu zachodzi według określonego programu, dzięki któremu dochodzi do organizacji poszczególnych funkcji organizmu. Podczas tego rozwoju czynniki pozagenetyczne oddziałują poprzez uwalniane substancji regulacyjnych. W odniesieniu do układu pokarmowego mnogość wytwarzanych przezeń czynników regulacyjnych uprawnia użycie określenia jako największego gruczołu wewnętrznego wydzielania organizmu. Wytwarzane czynniki regulacyjne, ich synteza i uwalnianie, są pod kontrolą złożonego systemu regulacji hormonalnej, nerwowej oraz immunologicznnej. Należą do nich także tzw. jelitowe peptydy regulacyjne, które odgrywają niezwykle istotną rolę $\mathrm{w}$ regulacji funkcji trawiennych. W niniejszym artykule przedstawiono postępy wiedzy o kontroli funkcji trawiennych $\mathrm{u}$ cieląt $\mathrm{z}$ udziałem jelitowych peptydów regulacyjnych głównie dotyczących regulacji wzrostu, motoryki i wydzielania soków trawiennych. Uwzględniono okres płodowy, noworodkowy i wczesny okres po odsadzeniu. Zgromadzona wiedza o biologicznych funkcjach i mechanizmach działania jelitowych peptydów regulacyjnych może pomóc w kontrolowaniu procesów wzrostu i dojrzewania przewodu pokarmowego, co jest szczególnie istotne w okresach o najwyższej śmiertelności, jak poród i odsadzenie. 